\title{
Praznina kao simptom emocionalne deprivacije u Heseovom Stepskom vuku
}

\author{
Branka B. Ognjanović*
}

Univerzitet u Nišu, Filozofski fakultet, Departman za nemački jezik i književnost

\begin{abstract}
Ključne reči:
\section{Apstrakt}

emocionalna deprivacija

U radu se analizira lik Harija Halera u romanu Stepski vuk Hermana Hesea kroz tumačenje praznine koja prožima njegovu dvostruku ličnost.

Hari Haler Cilj rada je da pokaže da se u hroničnoj praznini i nemogućnosti da pro-

Herman Hese tagonista sagleda i integriše aspekte sopstvenog identiteta nazire dugotrajna emocionalna deprivacija, odnosno nedostatak ljubavi i empatije psihološka praznina suicidalnost koje bi mu pružila okolina. Ukazuje se na biografske podatke relevantne za tumačenje romana, kao i na poreklo i odlike Halerove emocionalne nestabilnosti. Ističe se da psihološka shema emocionalne deprivacije životna kriza potiče iz odnosa porodice prema Haleru, te da posledice neempatičnog odnosa obuhvataju otuđenost, usamljenost, samoprezir i psihološku prazninu, od kojih Haler nastoji da pobegne autodestruktivnim ponašanjem. Analizom opisa osećaja unutrašnje praznine, ponora i pustoši, zaključuje se da je njena funkcija višestruka, te da je kao simptom istovremeno sredstvo skrivanja sebe i svojih nedostataka, kao i posledica udaljavanja od samoga sebe i gubitka smisla. Naposletku, ističe se i da Haler potencijalne katalizatore promene pronalazi u ženskim likovima, koji treba da ga, kao eksternalizovane projekcije njega samog, podstaknu na emocionalni razvoj i zauzimanje životnog stava okarakterisanog humorom kao načinom prevazilaženja egzistencijalne i psihološke prazninе. (примьено: 8. августа 2021; прихваћено: 23. октобра 2021)
\end{abstract}




\section{Uvod}

„Najmilosrdnija stvar na svetu, rekao bih, nesposobnost je ljudskog uma da uzajamno poveže sav svoj sadržaj. Mi živimo na blaženom ostrvu neznanja, usred mračnih mora beskonačnosti i nije nam namenjeno da putujemo predaleko."

(Lavkraft, 2018: 269)

Univerzum, čiji sićušni deo nastanjuju ljudska bića, iz naše perspektive beskonačan i nepojmljivog porekla i svrhe, indiferentan je prema dobrobiti vrste koja je igrom slučaja razvila (samo)svest. Iza vela čovekove svakodnevice, beskrajno ispunjene sadržajima da se ne bismo suočavali sami sa sobom, krije se egzistencijalni horor kolapsa smisla. Životi „satkani od užasa praznine“ (Jeftimijević Mihajlović, 2020: 763), „retko bez želja i na neki način srećni, najčešće: bez želja i pomalo nesrećni“ (Handke, 2020: 29), posledica su osećaja besmisla i nemoći u kontekstu sopstvene ograničenosti, bilo kao deo ličnih sudara s realnošću ili kao simptom doba u kome živimo.

Čovjek je nadaren razumom: on je život svjestan samoga sebe. [...] Ta svijest o sebi kao odvojenu biću, svijest o kratkom vijeku vlastita života, o činjenici da je bez vlastite volje rođen i da će protiv vlastite volje umrijeti, da će umrijeti prije onih koje voli, ili oni prije njega, svijest o osamljenosti i odvojenosti, o bespomoćnosti prema silama prirode i društva — sve to čini njegovu odvojenu, otuđenu egzistenciju nepodnosivim zatvorom. (Fromm, 1985: 20)

Sposobnost poimanja prolaznosti, smrtnosti, osuđenosti na samoću jer je po prirodi stvari sve u stanju neprestane promene, uključujući i odnose s drugima, izaziva teskobu i patnju. Praznina koja pritom nastaje može biti egzistencijalna ili psihološka, te je u svome psihološkom obliku definisana kao „disfunkcionalna strategija izbegavanja u situaciji duboke subjektivne patnje“, „stanje emocionalne anestezije“ (Didonna/Gonzalez, 2009: 126) ili "egzistencijalni vakuum“ (Didonna/ Gonzalez, 2009: 127; Frankl, 2019: 31)ํ․ Prema rečima Jeftimijević Mihajlović (2020: 764), pitanje je da li se prostori užasa praznine „'sabiraju', 'umnožavaju' pisanjem o njima, to jest da li postaju veći ili je pisanje način prevladavanja straha od njih“.

Za Hermana Hesea književnost bi bila vid terapije i put k izlečenju. Dok je stvarao Stepskog vuka (1927), i sam je „doživljavao krizu koja ga je dovodila do ruba samoubojstva“ (Žmegač, 1979: 12), pa je svoj zadatak definisao na sledeći način: „da pokažem, poštivajući neka za mene 'vječna' uvjerenja, siromaštvo duha u tendencijama našega vremena i razorno djelovanje tih tendencija čak i na suptilnije duhove i karaktere“ (Žmegač, 1979: 14). Početkom aprila 1916. godine patio je od nepod-

1 Eng. "Dysfunctional avoidance strategy in a situation of deep subjective suffering", "a state of emotional anesthesia", "existential vacuum". Citate je prevela autorka rada. 
nošljivih glavobolja i teških napada anksioznosti, što ga je navelo na odlazak kod psihoterapeuta Jozefa Bernharda Langa, učenika Karla Gustava Junga (up. Michels, 2009: 330-331). Krizno iskustvo i psihoterapija ostavili su trajan utisak na Hesea i naveli ga na temeljnu refleksiju, te je najpre u Demijanu (1919) izrazio zaključak da životni put postaje lakši tek kad čovek pronađe svoj san i da mnogi teže da ostvare snove, ali ne svoje sopstvene (up. Hesse, 2001: 346; 324, prema Michels, 2009: 332). Tokom perioda koji je potom usledio brak mu se raspao, a bližio se ujedno i njegov pedeseti rođendan. Nastupio je period očaja i nesrećnog osećaja rastrzanosti između dva poriva. Bio je spreman da se ubije, ali ga je privlačio i život ispunjen senzualnošću (up. Mileck, 1977: 65), što se odrazilo na njegovo dalje književno stvaralaštvo, a ponajviše na Stepskog vuka.

Roman Stepski vuk, osim tematike sudara starih i novih vrednosti kao odlike visokog modernizma, sadrži stoga izrazitu samorefleksiju protagoniste Harija Halera, čije je ime već jasna aluzija na Hermana Hesea. Tumačenju romana pristupalo se do sada dvojako - ili iz perspektive šireg istorijskog i kulturološkog konteksta ili pak oslanjajući se na psihološku analizu², pre svega kroz prizmu Jungove ideje o celovitosti $i$ individuaciji. Jung je individuaciju definisao, naime, kao „herojski $i$ često tragični zadatak, najteži od svih, koji uključuje patnju“ (Jung, 1973: 5041), a čiji je cilj „ništa drugo no da sopstvo bude lišeno lažnog omota persone, s jedne strane, i sugestivne moći iskonskih predstava, s druge strane ${ }^{\text {“3 }}$ (Jung, 1992: 174). Oslanjanje na Jungove teorije jedinstveni je aspekt Stepskog vuka kao izmenjenog oblika takozvanog razvojnog, odnosno obrazovnog romana (nem. Entwicklungs- und Bildungsroman), u kome se težilo da se prikaže razvojni put protagoniste sve do trenutka od kojeg prihvata moralne vrednosti društva i iznalazi način da izmiri lične potrebe, želje i senzibilitet s realnošću, merilima i potrebama svoga okruženja. Pojavljivanje besmrtnih velikana nemačke kulture Getea i Mocarta u Stepskom vuku nadovezuje se na postojeću tradiciju, no istovremeno je evidentno udaljavanje od nemačkog razvojnog romana kao humanističkog projekta, budući da se tematizuje razaranje celovitosti subjekta, ali ujedno i potraga za njom (up. Hatfield, 2003: 112; 116; Swales, 2005: 33). Lotar Ken (Köhn, 1969: 72) navodi da je Hese radikalno izrazio krizu klasične misli o obrazovanju i samim tim prevazišao humanističko-filozofski Bildungsroman, proširivši implikacije teksta idejama o internalizaciji ideala i uključivanjem mitova, simbola i arhetipova.

U radu će se nastojati da se iz psihološkog ugla sagleda protagonista, kako bi se na njegovom primeru pokazalo da psihička kriza, emocionalna otupljenost i otu-

2 Zbog obima rada nije moguće pružiti pregled svih dosadašnjih književnoanalitičkih razmatranja Heseovog Stepskog vuka - detaljan spisak vidi u Below, 2011. Malobrojne analize u okvirima srpskohrvatske germanistike poput Jerotićeve i Žmegačeve čak iz 1979. godine potvrda su potrebe da se Heseovim tekstovima ukaže veća pažnja na našim prostorima, naročito u kontekstu aktuelnih psihičkih izazova koje je prouzrokovala pandemija iz 2020. godine i savremenih istraživanja prema kojima je među novim generacijama, usled izmenjenih okolnosti života u današnjem svetu, sve učestalija izražena psihička kriza (up. Robinson/Wright, 2013).

3 Eng. "Individuation is an heroic and often tragic task, the most difficult of all, it involves suffering"; "The aim of individuation is nothing less than to divest the self of the false wrappings of the persona on the one hand and the suggestive power of primordial images on the other." 
đenost, čiji je simptom praznina, proizilaze iz Halerove emocionalne deprivacije ${ }^{4}$, odnosno manjka autentičnog kontakta s drugima i sa samim sobom, a pre svega s porodicom kao prvobitnim okruženjem i poreklom (samo)prezira, što onemogujuće kako unutrašnju integraciju delova njegove ličnosti, tako i integraciju u društvo. Porodica, iz koje se otisnuo u život, predstavlja „ishodište i, za mnoge od nas, naše odredište. [...] Zamišljati život bez porodice isto je što i zamišljati ga kao slobodan pad, bez sadržaoca, bez tla na koje treba da stanemo“ (Zvajg/Volf, 2016: 78-79). Hari Haler, po ugledu na arhetip večitog dečaka (lat. puer aeternus) koji odbija da odraste i da samostalno pronađe svoje mesto na ovome svetu, večito nosi u sebi osećaj odbačenosti i nepripadanja, te je okarakterisan kao "najnedruštveniji čovek“ (Hese, 2017: 5), duboko i beznadežno tužan i suštinski ispunjen sveprisutnim očajanjem (Hese, 2017: 11), „genije patnje“, u osnovi čijeg pesimizma se pak „nije nalazio prezir prema svetu, već prezir prema sebi“ (Hese, 2017: 12). Njegova osetljiva priroda, prinuđena na okruženost građanskom svakodnevicom i nedostatkom volje za smislom i višim vrednostima, prouzrokovala je u njemu čežnju za uklapanjem u društvo, ali i neprilagođenost koja se odrazila u podvojenoj ličnosti, jednoj produhovljenoj i drugoj životinjskoj, nagonskoj. Integracija disociranih, zavađenih aspekata selfa predstavljena je kao jedan od ciljeva borbe protiv ličnih unutrašnjih demona, ali i kao ključ za tumačenje nastranosti ne samo pojedinca, „već bolest[i] našeg doba, neuroz[e] onog pokoljenja kojem pripada Haler“ (Žmegač, 1979: 23). Pokazaće se da su večita čežnja i neuklapanje Harija Halera, kao i njegova „detinjasta sentimentalnost [...] kao nešto što je njemu daleko i nedostižno, kao dom i spokoj do kojih za njega nije bilo puta" (Hese, 2017: 18) posledica iskustava nedostatka sigurnosti i tople, brižne sredine koja poštuje suštinu njegovog bića.

\section{Poreklo i odlike emocionalne nestabilnosti Harija Halera}

Esencijalne potrebe na početku čovekovog života uključuju osećaj bezbednosti i stabilnosti uz zadovoljenje osnovnih egzistencijalnih potreba, konzistentnu emotivnu podršku i empatiju, strukturisano obrazovanje i vaspitanje, kao i pozitivne odrasle uzore. Halerovo vaspitanje bilo je pak zasnovano na slamanju duha, no „umesto da unište njegovu ličnost, uspeli su da ga nauče da mrzi sebe“ (Hese, 2017: 12). Nedostatak empatijskog odnosa majke prema njemu uslovio je divljenje građanskoj urednosti izdaleka, veličajući „blistavo čisto, tako besprekorno ljupko“ (Hese, 2017: 16) kao kod majke, no usled nedostatka privrženosti osuđen je na distancu i nemogućnost da i sam postane deo istog tog građanskog društva. Majka ipak ostaje jedna od fiksacija, koja će moći tek delimično da se razreši kasnije na relacijama Hari-Hermina i Hari-Marija. Detinjstvo lišeno roditeljske brižnosti i empatije pokrenulo je u njemu, dakle, neurotički proces samootuđenja i dubokog stida, odnosno

4 Emocionalna deprivacija kao termin odnosi se na nedostatak međuljudskih odnosa kroz koje bi pojedinac doživeo pažnju, uvažavanje i ljubav, prevashodno u kontekstu odnosa između deteta i osobe koja se primarno brine o njemu (najčešće majka). Ključna reč je svakako nedostatak (praznina) jer pojedinac oseća da nešto nedostaje što nikad neće moći da pronađe/nadomesti. Videti Životna zamka emocionalna deprivacija (Jang/Klosko, 2018: 154-178). 
neprihvatanja samoga sebe (up. Lancer, 2019: 3) i podele na dvostruku ličnost. Haler je stekao zavidna znanja i razvijao svoje intelektualne sposobnosti, ali nikada nije naučio kako da bude zadovoljan sobom, smatrajući da je zapravo upitno u kojoj meri je čovek i da je u dubini duše stepski vuk. Višestruka ličnost kao oblik disocijacije proistekao iz nedostatka podrške i ljubavi svedoči o tome koliko je „čovek isto toliko rob svog karaktera i unutrašnjih demona koliko i spoljašnjih autoriteta. Često se to ne shvati sve do druge polovine života, kada nam obično sine da je čovek sam sebi najgori neprijatelj, najoštriji kritičar, i najstroži u postavljanju zadataka sam sebi“ (Stajn, 2007: 46). Internalizacija kritičkog glasa roditeljskih figura načinila je od Halera biće koje konstantno teži tome da dostigne nesvakidašnje, u želji da nadomesti sopstvene zamišljene nedostatke. Ovaj „oblik samomržnje, koja će se doživeti kao unutrašnji kritički mučitelj, prezir prema telu ili odbacivanje suštinskog dela sopstvene prirode“ (Zvajg/Volf, 2016: 92) udaljava ga od nagonskog, divljaštva, svireposti i nesublimisane, sirove prirode kada je dominantniji čovek u njemu, a s druge strane iz vučje pozicije bije bitku protiv uljudnosti, produhovljenosti i umetničkih nastojanja - misli, osećanja, kulture, pripitomljene i sublimisane prirode - čovečje dimenzije Halera (up. Hese, 2017: 59). „Naš stepski vuk je tako živeo, osećajući se čas kao vuk, čas kao čovek, kao što je to slučaj kod svih polutana, ali kad je bio vuk, čovek ga je uvek vrebao, posmatrajući ga, procenjujući ga i osuđujući ga, a kad je bio čovek, to isto je činio vuk" (Hese 2017: 44).

Osciliranje između lica i naličja, između senke i persone, obeleženo je izraženom emotivnom nestabilnošću. Haler po odlasku saksofoniste Pabla uzvikuje: „Gde je otišao? Zar me svi napuštaju?“ (Hese, 2017: 210), sumirajući svoje burne i nestabilne odnose s drugim ljudima tokom života, a u koje čitalac stiče uvid: od nesrećnog odnosa s ženama, rasprave s profesorom i njegovom suprugom, sve do novih poznanstava s Herminom, Marijom i Pablom. Njegove emocije nepredvidive su i često negativnog i izbegavajućeg karaktera. Pokušava da se utopi u alkoholu - okružuju ga, naime, razne boce s pićem: crno, italijansko vino, burgunac, malaga, višnjevača (Hese, 2017: 14) - i obuzimaju ga plahovitost, nemir, strepnja, čežnja, bes, očaj, bol, naročito u kontekstu izbegavanja preteranog zadovoljstva:

[V]iše volim da u meni gori pravi satanski bol nego ta prijatna sobna temperatura. U meni tada plamti divlja žudnja za snažnim osećanjima i doživljajima, gori bes prema tom ufitiljenom, plitkom, normiranom i sterilnom životu i besomučna potreba da nešto razbijem na komadiće, kao, recimo, neku veliku trgovačku kuću, ili katedralu, ili samog sebe [...] da zavedem neku mladu devojku ili da nekolicini predstavnika građanskog staleža zavrnem šiju. (Hese, 2017: 27)

Burne želje za (auto)destrukcijom, euforičnom opasnošću i fizičkim užicima pokušaji su upravo da ne podlegne dosadi i da se ne suoči s unutrašnjom prazninom jer se protagonisti subjektivno čini da će lakše izaći na kraj sa svim tim ekstremnim stanjima i činovima nego sam sa sobom ukoliko bi se našao u prilici da se zagleda 
u svoju životnu priču i duboko ukorenjene obrasce ponašanja. Jerotić (1979: 33) navodi da Haleru nije ni potreban psihoterapeut „da mu vešto skrene pažnju sa egzistencijalno-ontoloških problema čoveka za sebe, pokazujući mu u sopstvenom 'neutralnom ogledalu' njegovu porodičnu i društvenu prošlost" - sve vreme se nazire nit koja jasno ukazuje na duboku anksioznost u međuljudskim odnosima, žudnju za nekom vrstom doma i čežnju za pronalaženjem smisla života. Haler sebe opisuje kao olinjalog pustinjaka „usred sveta čiji ciljevi nisu moji i čije mi radosti ništa ne znače“ (Hese, 2017: 30), dakle, živi u svetu u kome se ne ogledaju njegove ambicije i svetu lišenom ideala u koje (čak i previše) veruje. Stoga nastaje i rascep između realnosti i njegovih očekivanja, te je jedno od dominantnih osećanja pokušaj da se reši sopstvenog bića. Preintenzivni unutrašnji kritičar je destruktivno i agresivno nastrojen prema Halerovom egu i iz nasilnog odnosa prema sebi rađa se praznina iz koje ništa ne raste jer njegovom autentičnom biću nije ni dozvoljeno da raste i da se razvija ka celovitosti. Svakodnevica koju živi je „život samoubice [...], teške depresije i on bi ostajao danima u krevetu ne tražeći da jede” (Hese, 2017: 21) jer je „dovoljan i najmanji spoljašnji udarac ili neka sitna unutrašnja slabost pa da padne u ambis“ (Hese, 2017: 50). Neizbežna posledica je i životna kriza koja ga obuzima i motiviše da isplanira da će na svoj pedeseti rođendan napokon okončati dugogodišnje čekanje i prerezati sebi grkljan. Ipak, on svoje samoubistvo ne posmatra samo iz ličnoga ugla, već prezir prema sebi ispoljava i u obliku kulturnog pesimizma, negujući opšti resantiman i defetizam.

Neću samo ja, sutra ili prekosutra, završiti zakopan u blatnjavu ilovaču uz zbunjenost i pritvornost učesnika sprovoda, već se tako završava sve, sve naše težnje, sva naša kultura, sva naša vera, sva naša životna radost i volja za životom, koja je tako bolesna i koja će uskoro biti tamo zakopana. (Hese, 2017: 78-79)

Ljudska nastojanja, nezavisno od toga da li se odvijaju na individualnom ili globalnom planu, osuđena su na propast, prolaznost i smrt iz Halerove perspektive. U njegovom pogledu na svet izražene su negativne emocije koje dostižu ekstremne vrednosti poput suicidalnih ideja i mračnog, ciničnog vrednovanja društva, istorije i kulture. Svet i ljudska sudbina posmatraju se kroz prizmu suštinski nesrećnog i emotivno nestabilnog čoveka, kome nikada nije pružena emotivna podrška i koji potom sebi nikada nije ni dozvolio da u odnosima s drugima i svojim razmišljanjima razvije pozitivne stavove, poistovećujući podsvesno negativizam i patnju s uzvišenošću i posebnošću.

\section{Psihološka praznina kao posledica i simptom emocionalne deprivacije}

Psihološka praznina je za Halera vid bekstva, no da li se radi o projektovanju sopstvenog osećaja neadekvatnosti na sve što je čovek stvorio ili je pak zaista izgubljena volja za uzvišenim vrednostima i smislom predstavlja kompleksno pitanje. Haler svakako nije jedina usamljena i otuđena osoba u doba u kome uloga tradicije, 
različitih oblika udruživanja i zajedništva i saosećanja s drugima slabi u korist individualizma. Ispraznost spoljašnjeg sveta ogledalo je unutrašnjeg stanja modernog čoveka:

Onaj ko je doživeo drugačije dane, [...], ili one dane duhovnog umiranja, zlobne dane pune unutrašnje praznine 5 i očaja, kad nam se [...] na svakom koraku čovečanstvo i takozvana kultura, u svom lažnom, prostačkom i šupljem vašarskom sjaju, rugaju kao neko sredstvo za povraćanje, koncentrisano i dovedeno do vrhunca nepodnošljivosti u svom sopstvenom, bolesnom Ja; onaj ko je, dakle, doživeo takve paklene dane, taj može da bude zadovoljan ovim normalnim, nepotpunim kao što je bio ovaj današnji. (Hese, 2017: 26)

Kulturu Hari doživljava kao veštačku, lažnu i kao privid, naročito u trenucima kada i njega samog more odsečenost od emocija ili duboka patnja. Premda je genije patnje, i u njegovom životu postoje periodi ravnodušnosti i svakodnevice bez burnih osećanja, no trenuci istinske radosti nisu deo njegovog životnog iskustva i pripisani su takođe nepodnošljivoj kulturi i njenom šupljem sjaju. Ona mu se ruga jer se depresivnom čoveku čini da je uspeo da se zagleda u pravu istinu koja se prikriva iza vela normalnog - činjenicu da su svi ljudski napori uzaludni, uključujući i napore da se stvore i neguju kulturni sadržaji i tradicija, i da služe tome da se izbegne jedina izvesnost u životu, naime, da smo svi osuđeni na prolaznost, prosečnost, usamljenost i zaborav. Unutrašnja praznina pojavljuje se kod Halera u danima duhovnog umiranja kao znak da se utonućem u nihilizam udaljio od samoga sebe i životne svrhe i otuđio od drugih ljudi, večito osuđen na samoću stepskoga vuka. Izlaz ne pronalazi na ovome svetu, već razvija svoje suicidalne planove: „a kad se iz nekog razloga osećao posebno loše, ako bi pored osećaja pustoši, usamljenosti i podivljalosti došle i neke nove patnje i gubici, mogao je da im kaže: 'Sačekajte još samo dve godine, pa ću zagospodariti vama!'“ (Hese, 2017: 52). Razmišljanja o samoubistvu su retka uteha i preusmeravanje pažnje s anesteziranih emocija koje su samo prikrivene i utišane, ali i te kako postojeće. Koliko god da nastoji da ih umrtvi, neizbežno je da ga i u stanju dominantnog ahumanog (animalnog) aspekta ličnosti prožima bol i da „i u vuku postoje duboki ponori i da i vuk pati“ (Hese, 2017: 65). Prezir prema telu, koje se treba razoriti putem samoubistva i koje je materijalizacija ega, proizilazi upravo iz napada surovog unutrašnjeg kritičara. Podređivanje tela umu vodi ne samo ka želji za fizičkim ubijanjem tela i/ili psihičkim ubijanjem senke stepskoga vuka, već je i manifestacija razotkrivanja human(ističk)e iluzije o ljudskoj bitnosti (up. Mathäs, 2014). Halerov izraziti antihumanistički stav poseduje potencijal da izrodi novo shvatanje ličnog i univerzalnog ljudskog koje prevazilazi brojne dihotomije i podvojenosti: um/telo, kultura/priroda, produhovljenost/primitivnost, racionalnost/osećajnost, nepromenljivost/fluidnost, ali i u unutrašnjem svetu Harija suprotstavljenost persone i senke. Haler opisuje kako je svaki put „skidanju maske i

5 Autorka rada je označila reči praznina, pustoš, ponor kurzivom u citatima. 
rušenju ideala prethodila ona užasna pustoš i tišina, ono samrtno tištanje, ona usamljenost i prekidanje svih veza sa svetom, onaj prazni, pusti pakao očajanja, lišen svake ljubavi, kroz koji sam sada opet morao da prođem“ (Hese, 2017: 69). Praznina, stoga, osim što je nesrećno aktivirani odbrambeni mehanizam, ujedno otvara i brojne mogućnosti za ponovno rođenje, integraciju odbačenog i zanemarenog ili novo osmišljavanje sebe i samim tim razvoj sebe 'ubijanjem' nefunkcionalnih elemenata psihe ili pak ljudskog iskustva.

Prvi korak je, uz osamu i neizbežnu patnju, i temeljna refleksija, te se Haler pita „kako je došlo do ove ukočenosti, ove mržnje prema sebi i drugima, do gušenja svih osećanja, do ove duboke, opake mrzovolje, do ogavnog pakla praznine i očajanja“ (Hese, 2017: 76). Svoj nedostatak neretko dovodi u vezu s očajanjem ili paklom, te život sagledan kroz kritičku prizmu naziva glupim i površnim, beznadežno tužnim i ispraznim (up. Hese, 2017: 79-80). Negativni doživljaji i događaji neminovnost su u okviru kratkotrajnog ljudskog života, ali kod stabilnih ljudi nisu jedino što ga odlikuje, već se naizmenično smenjuju periodi patnje s periodima sreće i užitka. Porodica koja nije lišavala ljubavi ugradila je u njih veštinu regulacije sopstvenih emocija, sagledavanja negativnih iskustava iz različitih, dugoročnijih i optimističnijih perspektiva, kao i suštinsku izdržljivost i 'antikrhkost'. Hari Haler, poput i samoga Hesea koji je pretrpeo napuštanje i izdaju roditelja u detinjstvu kad je $s 15$ godina završio u mentalnoj instituciji zbog bekstva iz škole i pokušaja samoubistva, nije sposoban da umiri sebe u trenucima kad se njegova posramljenost i njegovi nedostaci razotkrivaju pred drugima. Bekstvo od svakodnevne egzistencije i stvarnosti u sanjarenja i momente očaja jedna je od posledica ključnog traumatičnog iskustva - nemogućstva da se ispune očekivanja roditelja, a druga je upravo nastojanje da se kroz pisanje prouče unutrašnji konflikti i da se ukaže na njih (up. Michels, 2009: $323,235)$. Praznina je oblik bekstva i zaštite kome Haler podleže, no ujedno i njegova istinska priroda nakon što nestanu svi disocirani fragmenti identiteta, uključujući oba ekstrema produhovljenog čoveka Halera i usamljenog i primitivnog vuka. Njegova srž je sačinjena od vakuuma, crne rupe, praznog platna na kome se oslikavaju dve ličnosti, sve dok se ne razbiju u paramparčad u sudaru unutrašnjeg ambisa sa spoljašnjim. „Poznato vam je bilo čitavo ovo naše užasno lebdenje u praznini, u nesigurnom, činjenica da smo osuđeni na prolaznost, na nepotpunu vrednost, na večite pokušaje i na diletantizam“" (Hese, 2017: 97). Iznova se kristališe svest o tome da su sva čovekova nastojanja uzaludna, da su vreme i prostor koje zauzima u kosmičkoj perspektivi neznatni i da je cela borba oko kulture i nauke jalov pokušaj da se ostavi trag iza sebe. Hese navodi da smo „ispali iz prirode i visimo u praznini“ (Hese, 2017: 127), praznini smisla i egzistencijalnom vakuumu.

Mogućnost popunjavanja praznine očitava se u pojmu umetnost izgradnje (up. Hese, 2017: 193), a na ličnome planu Harija Halera u odnosima s Herminom i Marijom i tokom kasnijeg ulaska u tzv. magično pozorište koje na njega ima psihoterapeutsko dejstvo jer se iznova susreće sa svojom prošlošću, uči da je sagleda iz drukčijeg ugla i da je proživi, odnosno izgradi, na način koji je prilagođeniji društvu. Žmegač (1979: 19, 17) navodi da su Hermina i Marija „njegove učiteljice“, koje ga uvode u 
„svijet kultivirane senzibilnosti“, te da se radi o „bitnom novumu“ u Halerovim intimnim odnosima kao „prodor[u] u čulnost koja može pretendirati na to da se smatra znakom totaliteta“. Hermina se tumači kao „veliki Posrednik između ovostranog i onostranog, između nagona i duha, između pakla i raja, zemlje i neba, neka vrsta 'čuvara praga'“ (Jerotić, 1979: 37), kao vodič, iskušenje i glasnik platonskog dualizma (up. Webb, 1971: 117). Njena uloga je da Halera kao alter ego navede na unutrašnju transformaciju kroz spoznaju suptilnijih osećanja i iskustava, koja uključuju i vreme s Marijom, ljubavnicom, odnosno još jednom zamenom za majčinsku figuru.

I tako su u ovoj prvoj, nežnoj noći iskrsle preda mnom brojne slike mog života, koji je dugo bio prazan, siromašan i bez ikakvih slika. Eros je kao magijom otvorio duboke i bogate izvore, i, videći koliko je moj život ispunjen slikama, koliko je duša sirotog Stepskog vuka puna dalekih, večnih zvezda i sazvežđa, moje srce je na trenutke prestajalo da kuca, očarano i tužno. (Hese, 2017: 140)

Haler svoju dotadašnju prazninu postepeno ispunjuje uživanjem u životu kroz ples, muziku, životnu radost i lakoću postojanja. Za njega su ranije i telesni užici pripadali građanskoj sferi, tradicionalnom konceptu braka i svrsi produžetka vrste, a ujedno i primitivnom i ispraznom. Marija ga priprema za shvatanje života koje je spontanije i manje ozbiljno, predstavljajući lekciju o prolaznosti, večitim promenama i prihvatanju nje kao privremenog gosta, s kojim može ostvariti kontakt, a potom se i pomiriti s time da je neuhvatljiva i da je sasvim moguće, umesto previše razmišljanja, jednostavno živeti ovde i sada. Za Halera je koncept života u sadašnjosti, bez anksioznosti o budućnosti i depresivnih razmišljanja o prošlosti, nepoznanica i intrigantan, tako da je sasvim nužan deo njegovog preobražaja čiji su katalizatori Hermina i Marija. U susretima s Marijom oseća „goruću žudnju i strah koji me je gušio, pa sam se grčevito hvatao za Mariju i ponovo sam, strastveno i požudno prešao preko svih staza i bogaza njenog vrta, još jednom sam zagrizao plod sa rajskog drveta" (Hese, 2017: 158). Kroz prihvatanje svoje nagonske strane i otkrivanje strasti ka životu, Haler uči kako da živi i da voli. Marija ga prihvata bezuslovno poput figure majke koja mu pruža utehu, no prisutna je, ipak, samo privremeno, na trenutke, podstičući ga na osamostaljenje.

Do naredne tačke u okviru svoga puta individuacije dolazi ubistvom Hermine/ Hermana, koje je u njemu probudilo iznova osećaj praznine: „a iz mrtvog lica, mrtvih belih ramena i mrtvih belih ruku polako se prikradala neka jeza, zimska pustoš i usamljenost, neka hladnoća koja je polako, veoma polako rasla i od koje su počele da mi se koče ruke i usne“ (Hese, 2017: 210). Posmatrajući njeno hladno telo, nakon što ju je ubio tokom boravka u magičnom pozorištu, tj. lutanja po svojoj podsvesti gde „prizori koji mu se pružaju predstavljaju zapravo projekcije njegovih podsvjesnih želja, njegovih slutnji i mora“ (Žmegač, 1979: 23), opet ostaje sam, ali ovoga puta svesniji svojih nedostataka. Herminu kao spoljašnju projekciju dela sebe koji ne prihvata morao je da ukloni da bi pokušao da je integriše, a svakoj vrsti integracije 
takođe prethodi nepodnošljiva emotivna bol. Haler „zna da postoji ogledalo u koje bi morao da pogleda, a užasno se plaši da to učini“ (Hese, 2017: 58), ali u trenutku kada bi se istinski mogao zagledati u svoju mračnu stranu mogao bi da napreduje u svome izlečenju i produktivnijem umanjenju psihološke praznine. Njegova mračna strana ovde obuhvata, osim seksualnog, i agresivni nagon, ali i životni elan, osećajnost i otvorenije odnose prema drugim ljudima koji potpadaju pod ženski princip otelovljen u Hermini. Prema rečima Jerotića (1979: 39):

[I]zgleda da mi ne možemo dospeti do pozitivnih, još više, stvaralačkih snaga u sebi, niti ih početi korisno upotrebljavati u upoznavanju realnosti koja je, to treba istaći, beskonačna, sve dotle dok nismo izbacili iz sebe, svesno ih prepoznavajući, ali i duboko emotivno proživljavajući, sve negativne, tzv. zle strane ljudske prirode.

Neophodno je stoga da Haler prestane da prikriva problematiku svoga bića i unutrašnju prazninu elementima koji je umnožavaju, već da se suoči s uzrocima svoje nesreće i da ublaži svoj kritički super ego. Predočava mu se da treba da prihvati humor života, umesto što traga za uzvišenom patnjom: „Ali, naravno, vi ste spremni na sve na svetu samo ne na ono što se traži od vas! Spremni ste da nožem ubijete devojku, spremni ste da budete svečano pogubljeni, sigurno biste bili spremni i da sto godina mučite i bičujete sebe“ (Hese, 2017: 216). Ukoliko bi Haler bio sposoban da nauči lekciju, njegov put individuacije bio bi adekvatno usmeren. Onda bi se „lišio glavne prepreke za svaki pravi preobražaj, gordosti. Početak svakog višeg humora je da čovek, kako piše Hese, ne shvata više ozbiljno svoju sopstvenu ličnost“" (Jerotić, 1979: 35). Premda su ga okolnosti podstakle na put promena, ostaje neizvesno u kojoj meri je opisana faza bila uspešna ${ }^{6}$, no sposobnost samorefleksije i uviđanja sopstvenih obrazaca ponašanja svakako predstavlja bitan preduslov za Halerov dalji razvoj i iznalaženje načina za rast na polju osetljivosti, prihvatanja i proživljavanja sopstvenih osećanja i negovanja odnosa s drugima.

\section{Zaključak}

Hari Haler, odnosno Stepski vuk, opisuje osećaj unutrašnje praznine, pustoši i ponora u trenucima duhovnog umiranja, očaja i usamljenosti, kako u kontekstu lične patnje, tako i u odnosu prema spoljašnjem svetu i njegovom prividnom sjaju. Njena funkcija je višestruka: praznina je sredstvo prikrivanja sebe/srama/osećanja od sebe i drugih, nedostatak osećaja ličnog i kolektivnog smisla u kosmičkoj perspektivi, nemogućnost upoznavanja samoga sebe i razvoja bez smernica i brige najbližih bića, posledica odvajanja od osobe koja je ujedno i deo njega. Praznina je realnost ljudskog postojanja, ali ne mora biti nužno i nihilizam jer upravo „u ništavilu leži beskonačan potencijal“ (Masuno, 2019: 35). Harijevo iskustvo iz magičnog pozorišta/podsvesti pokazalo je da je lična istorija posve subjektivna i podložna re-

6 Ubistvo Hermine tumačeno je iz više uglova: kao oživljavanje građanskog aspekta njegove ličnosti, kao simbolično samoubistvo ili pak kao nemogućnost da se integrišu nagoni (up. Swales, 2005: 39). 
interpretaciji, te da su i najzapostavljeniji aspekti psihe, čak i nakon dugoročne lišenosti emocionalne podrške, podložni razvoju samo ukoliko je neko spreman na to jer je, naposletku, čovek „biće koje neprekidno odlučuje o tome šta je on; biće koje u sebi nosi podjednaku mogućnost da se spusti na nivo životinje ili da se uzdigne na nivo sveca“" (Frankl, 2019: 106).

\section{Literatura}

Below, J. (2011). Hermann Hesse Bibliographie: Sekundärliteratur 1899-2007. Berlin: Walter de Gruyter.

Didonna, F., Gonzalez, Y. R. (2009). Mindfulness and feelings of emptiness. In F. Didonna (Ed.), Clinical Handbook of Mindfulness (pp. 125-151). Springer Science + Business Media. https://doi.org/10.1007/978-0-387-09593-6_9

Frankl, V. (2019). Psihoterapija i egzistencijalizam (N. Dragojević i A. Đ. Milenković, prev.). Beograd: Kontrast.

Fromm, E. (1985). Umijeće ljubavi (H. Lisinski, prev.). Zagreb: Naprijed.

Handke, P. (2020). Nesreća bez želja (Ž. Radaković, prev.). Beograd: Laguna.

Hatfield, H. (2003). Accepting the Universe: Hermann Hesse's Steppenwolf. In H. Bloom

(Ed.), Hermann Hesse (pp. 111-122). Philadelphia: Chelsea House Publishers.

Jang, Dž. E., Klosko, Dž. S. (2018). Osmislite život iznova. Kako prerasti sputavajuće psihičke sheme. Shema terapija u praksi (J. Đerić Počuča, prev.). Novi Sad: Psihopolis institut i Beograd: Centar za shema terapiju.

Jung, C. G. (1973). Collected Works of C. G. Jung: The First Complete English Edition of the Works of C. G. Jung. London: Routledge.

Jung, C. G. (1992). Two Essays on Analytical Psychology (R. F. C. Hull, Trans.). London: Routledge.

Köhn, L. (1969). Entwicklungs- und Bildungsroman: Ein Forschungsbericht. Stuttgart: J. B. Metzlersche Verlagsbuchhandlung.

Lancer, D. (2019). Perspectives on Emptiness. Psychology and Behavioral Science: International Journal, 12(4), 1-9. doi: 10.19080/PBSIJ.2019.12.555844

Lavkraft, H. F. (2018). Zov Ktulua (D. Ognjanović, prev.). U Nekronomikon: najbolje horor priče Hauarda F. Lavkrafta (str. 269-298). Novi Sad: Orfelin.

Masuno, Š. (2019). Zen: jednostavno srećan život (J. Palavestra, prev.). Beograd: Vulkan izdavaštvo.

Mathäs, A. (2014). From Anti-humanism to Posthumanism: Hermann Hesse's Steppenwolf. Konturen, 6, 179-209. doi: http://dx.doi.org/10.5399/uo/konturen.7.0.3500

Michels, V. (2009). Hermann Hesse and Psychoanalysis. In I. Cornils (Ed.), A Companion to the Works of Hermann Hesse (pp. 323-344). Rochester, NY: Camden House.

Mileck, J. (1977). Hermann Hesse: Biography and Bibliography (Vol. 1). Berkeley: University of California Press.

Robinson, O. C., Wright, G. R. T. (2013). The prevalence, types and perceived outcomes of crisis episodes in early adulthood and midlife: A structured retrospectiveautobiographical study. International Journal of Behavioral Development, 37(5), 407-416. https://doi.org/10.1177/0165025413492464 
Stajn, M. (2007). Jungova mapa duše: uvod (Ž. Prinčevac de Villablanca, prev.). Beograd: Laguna.

Swales, M. (2005). New Media, Virtual Reality, Flawed Utopia? Reflections on Thomas Mann's Der Zauberberg and Hermann Hesse's Der Steppenwolf. In I. Cornils and O. Durrani (Ed.), Hermann Hesse Today / Hermann Hesse heute. Amsterdamer Beiträge zur neueren Germanistik, 58 (pp. 33-40). Amsterdam: Rodopi.

Webb, E. (1971). Hermine and the Problem of Harry's Failure in Hesse's Steppenwolf. Modern Fiction Studies, 17(1), 115-124.

Zvajg, K., Volf, S. (2016). Romansa sa Senkom: skrivena moć tamne strane ljudske duše (B. Stojiljković, prev.). Beograd: Fedon.

Жмегач, В. (1979). Хесеов Степски вук - данас. У Херман Хесе (стр. 7-28). Београд: Коларчев универзитет.

[Žmegač, V. (1979). Heseov Stepski vuk - danas. U Herman Hese (str. 7-28). Beograd: Kolarčev univerzitet]

Јеротић, В. (1979). Антипсихијатријски погледи у Степском вуку Хермана Хесеа. У Херман Хесе (стр. 29-44). Београд: Коларчев универзитет.

[Jerotić, V. (1979). Antipsihijatrijski pogledi u Stepskom vuku Hermana Hesea. U Herman Hese (str. 29-44). Beograd: Kolarčev univerzitet]

Јефтимијевић Михајловић, М. (2020). Horror vacui или ужаси празнине у роману Несрећа без жеюа Петра Хандкеа. Зборник Матице српске за језики књижевност, 68(3), 759-774.

[Jeftimijević Mihajlović, M. (2020). Horror vacui ili užasi praznine u romanu Nesreća bez želja Petra Handkea. Zbornik Matice srpske za jezik i književnost, 68(3), 759-774]

\section{Izvori}

Hese, H. (2017). Stepski vuk (M. Simić, prev.). Podgorica: Narodna knjiga/MIBA Books. 


\section{Branka B. Ognjanović}

\section{Summary}

\section{EMPTINESS AS A SYMPTOM OF EMOTIONAL DEPRIVATION IN HERMANN HESSE'S STEPPENWOLF}

The paper presents an analysis of Harry Haller, the protagonist of the novel Steppenwolf by Hermann Hesse. The focus of the analysis is the emptiness which encompasses his double personality. The goal of the paper is to show that the chronic emptiness and the inability to see and integrate the aspects of one's identity, as exhibited by the protagonist, can be interpreted as a consequence of a long-term emotional deprivation, i.e. lack of love and empathy provided by other people. The paper includes the biographical data relevant for the reading of the novel, as well as an analysis of the origins and the characteristics of Haller's emotional instability. The emphasis is on the premise that the psychological schema of emotional deprivation stems from the relationship of Haller's family towards him, and that the outcomes of a non-empathic relationship include alienation, loneliness, self-contempt and psychological emptiness, which Haller attempts to avoid through autodestructive behaviour. The analysis of the descriptions of the feeling of emptiness shows that it is a symptom of hiding one's self and one's shortcomings, as well as a consequence of abandoning one's self and the loss of meaning. In the end, the potential catalysts for change are the female characters, who, as externalised projections of Haller's self, should inspire him to grow emotionally and take on an outlook on life characterised by humour as a way to overcome existential and psychological emptiness.

\section{Key words:}

emotional deprivation, Harry Haller, Hermann Hesse, life crisis, psychological emptiness, suicidal ideation 